Popular Music (2020) Volume 39/3-4. (C) The Author(s), 2021. Published by Cambridge University Press on behalf of Popular Music. This is an Open Access article, distributed under the terms of the Creative Commons Attribution licence (http://creativecommons.org/licenses/by/4.0/), which permits unrestricted re-use, distribution, and reproduction in any medium, provided the original work is properly cited, pp. 568-584

\title{
The country and Irish problem
}

\author{
STAN ERRAUGHT \\ University of Leeds, Music, Music, Leeds LS2 9JT, UK \\ E-mail: s.erraught@leeds.ac.uk
}

\begin{abstract}
Country music has been popular in Ireland since the 1960s, most notably in the work of homegrown performers. Despite the durability of this appeal in the face of huge changes in Ireland and in the Irish music industry over a half-century, it remains curiously underexamined in the literature on Irish popular music. In this paper, I wish to argue the following:

(1) Country music did not simply arise 'naturally' in Ireland as a reflection of musical or national characteristics: it was promoted as such.

(2) Both popular and academic literature on the subject have tended to unreflectively echo the narrative that was introduced alongside the music in order to fix its audience.

(3) In so doing, the literature reproduces a set of anxieties about modernity as it arrived in Ireland, about the postcolonial condition and about authenticity, even as it attempts to locate Irish popular music within these concerns.
\end{abstract}

\section{Introduction}

In the late 1960s, the pages of New Spotlight magazine, then Ireland's only national popular music journal, were filled with comment, features and readers' letters discussing the so-called 'country boom'. The sustainability, authenticity, even the existence, of this phenomenon were discussed at length and from many conflicting points of view. The topic under discussion was the divergence, over the previous few years, in the repertoires of many groups on the showband circuit, itself a distinctively Irish phenomenon. During the peak years of these groups, spanning the late 1950s to the mid-1960s, their music would encompass most popular genres.

Audiences got a pot-pourri: rock-and-roll, country and western, skiffle, Dixieland, céili, waltzes, Irish ballads. Versatility was the name of the game. (Brendan) Bowyer [singer with the Royal Showband, one of the most popular of that ilk] sang ballads and rock equally well. He could hit the high notes with the Holy City or Boolavogue one minute, and gyrate to the Hucklebuck the next. (Power 1990/2000: 24) ${ }^{1}$

By the later 1960s, dealing with competition from other sectors of a growing Irish music industry, the showbands had begun to take on more distinct musical identities

1 'The Holy City' was a devotional song, 'Boolavogue' was a 'rebel' anthem, commemorating the exploits of a heroic priest during the rebellion of the United Irishmen in 1798, and 'The Hucklebuck' was a huge hit for Bowyer and the Royal Showband, a cover of a jazz tune from 1949 that contributed to a dance craze. It is still the tune that most people in Ireland would think of first when showbands are mentioned. 
and to dip their toes in 'original' or at least specially written material. Where previously, accuracy in the reproduction of the hits of others, and the liveliness of the stage show, were almost the only criteria for success, now an 'angle' was required. Broadly speaking, the showband scene split into two camps: country and pop.

Half a century later, in 2020, with the showbands a distant memory, and the circuit of ballrooms that nurtured them long converted into the furniture showrooms and carpet warehouses that skirt many small Irish towns, country music remains popular in Ireland. The means of production, marketing and consumption have changed as with every other sector of the music industry, but, in common with country artists in its 'home' territory of the USA, Irish artists within the genre, such as Ray Lynam and Susan McCann, have extraordinary commercial longevity. New artists - Nathan Carter for example - continue to emerge alongside the veterans and it is at least possible, by some metrics, that country remains the most popular genre of commercial music in Ireland. ${ }^{2}$ Despite this, it is underrepresented in coverage in the national media, and it falls to the local radio stations in the music's heartlands, the 'Border, Midlands and West' of the Republic and the western counties of Northern Ireland, to sustain it.

This neglect is paralleled in the academic literature on popular music in Ireland. ${ }^{3}$ To pick but one example: In The Irishness of Irish Music, John O'Flynn notes that 'country and Irish' is 'arguably one the most popular forms of music in Ireland' (2009, p. 32), but later suggests that it might be part of a group of what he terms, following Ruth Finnegan (2007), 'unspectacular' music scenes in the country, excluded from 'histories and contemporary accounts of Irish music' (O'Flynn 2009, p. 142). He suspects that this exclusion, in the case of country and Irish, might be a reflection of the way in which '[Daniel O'Donnell's fan base and the music of which he was by then the most popular exponent] appears to fly in the face of contemporary Irishness and music' (O'Flynn 2009, p. 142).

Gerry Smyth, in Noisy Island, makes a somewhat similar point about the reluctance of the literature to deal with the showband scene. He argues that, in the accepted narrative of Irish popular music, imbued with a belief in the primacy of folk and/or rock as the carriers of expressive authenticity, the showbands are 'invariably represented ... as a problem which rock, thankfully, solved' (Smyth 2005, p. 15). Smyth and O'Flynn barely mention country music otherwise, and discussion of the genre and its audience is almost non-existent in the literature on Irish popular music. When it is mentioned, two tropes predominate. One is variations on the theme set out by O'Flynn above: the idea that country is connected in some way with an oldfashioned, un-contemporary Ireland - a throwback. The second is the view, popularised in the early 1990s by a TV series and spin-off book, Bringing it all Back Home, that traced, in a somewhat selective manner, the influence of Irish music on (mostly) American forms and their return home in the form of rock, country, and related genres (O'Connor 1991). This view is summarised by Ó Súilleabháin: 'what

2 For example, the biggest selling series of concerts in Ireland ever was a five-night run for Garth Brooks at Croke Park in 2014: a total of 420,000 tickets were sold. Given the population of Ireland then was in the region of $6.5 \mathrm{~m}$ (both jurisdictions), that suggests that one in 15 people on the island had a ticket. As it happens, the concerts did not go ahead owing to the promoter, Aiken promotions (whose founder, Jim Aiken, was promoting showbands in Belfast in the 1960s), being unable to get a licence for two of the five concerts from Dublin City Council.

3 As also noted by Paul Maguire (2012) and by Rebecca S. Miller (2014). I am grateful to a reviewer of an earlier draft of this paper for drawing my attention to both of these. This absence is also noted by Blake (2013). 
Ireland is getting back in "Country music" is an American popularisation of its own music tradition' (Ó Súilleabháin 1981, p. 86). Both views are, at best, problematic. I will interrogate the first of these a little more closely later in this paper; the second I do not propose to look at in any depth. My view, which I will simply assert, is that the popularity of country music in Ireland has little to do with any real or imagined family resemblance to a ballad tradition that emigrated in the 18th and 19th centuries and is held to have been preserved in the music of Appalachia.

Two preliminary claims need to be advanced here: one, Irish country music was a product of the showband scene, and in order to understand this we need to understand how the showband scene worked and how, as its dominance was threatened by other forms of entertainment, actors within that scene adopted country music as a form that could maintain the appeal of the showband formula, the dance halls in which they played and the social opportunities the halls afforded, and retain a multigenerational audience in the face of competition from rock and folk. The second claim is this: the continued popularity of country in Ireland, and among Irish diasporic communities, and the attendant disavowal of that popularity in both popular histories of Irish music and in the academic literature, are rooted in the discourse that was actively and consciously generated in the media at the time of 'the country boom'. The people who promoted country music then did what promoters often do: sought to summon up an audience by creating an imagined community around a musical form, distinctive attendant social practices and, in this case, a covert appeal to national sentiment. Country, which was no more or less an import from the US music scene than rock ' $n$ ' roll or soul, was marketed as something that the Irish have 'always' had a special affinity for, an affinity sometimes attributed to an 'essential' rurality or conservatism in the national character and to a supposed link between the folk ballads of Great Britain and Ireland and the roots of country music. What is odd is that academic literature on popular music in Ireland, and even more so, popular accounts of the subject, have taken these constructs at face value and shown little inclination to unpick the threads.

To support these claims, I will first track the 'country boom' and its antecedents in the pages of Spotlight and New Spotlight through the mid-to late 1960s, to show that many of the arguments for and against country music that were aired then remained influential in the post-facto critical literature. Crucially, these narratives did not simply 'emerge' but were consciously nurtured by the music business in order to sell the new music. I will then follow these threads as they became part of the discourse around country music in academic literature on popular music in Ireland. Finally, I will show how some of that discourse, even as it attempts to contextualise the showband story and the growth and sustained popularity of country in Ireland in a more sympathetic manner, still repeats certain assumptions regarding the normativity of one particular model of development and 'authenticity' within popular music, and fails to properly account for the tendency of dominant narratives to colonise even as they try to explain the post-colonial situation. ${ }^{4}$

This last point is perhaps the most ambitious. I will say more later, but the argument is roughly this: Ireland and Irish society may be viewed as postcolonial, but were, and are, also distinctive among former imperial possessions in having

\footnotetext{
4 As is conventional, I use the term 'post-colonial' (with hyphen) to denote the historical state of affairs Ireland after the colonial period - and 'postcolonial' (un-hyphenated) to refer to the culture of the period, where it is assumed that the legacy of the colonial era has not being superseded.
} 
been so close to the imperial power as to be considered not a possession but an integral part of the home nation. As a consequence of this, the establishment, or re-establishment, of a distinct national cultural identity, so greatly desired by the revolutionary generation at the end of 19th and early 20th centuries, was, in practice, impossible to achieve. Separatist aspiration was replaced by an anxiety about the shared cultural space between Britain and Ireland, amplified by continued patterns of emigration from rural Ireland to English and Scottish cities. This anxiety was further modulated by a hostility to modernity - understood as secularist, irreligious and a disruptive of traditional morality - exhibited by various agents in the emerging years of the Irish state. My contention with regard to popular culture and popular music is twofold: firstly, a desire to distinguish 'Irishness' from mass British culture displayed a kind of willed exceptionalism that privileged the real cultural and social differences between a largely rural and agricultural society and its urban and industrialised neighbour while attempting to suppress the continuities. Secondly, the asymmetry between a small and still relatively underdeveloped Ireland and the rich, developed, neighbouring power meant that a sense of cultural lag and, indeed, of inferiority, was never far from the surface, even as it was denied. The Irish music industry was perhaps uniquely unfortunate through the 1960s and into the 1970s to be in such proximity to a British counterpart that was perhaps second only to the US in creativity and commercial clout - and to be unprotected by a language barrier, a prophylactic that allowed distinctive variants of modern pop forms to develop in other European countries, in South America and in Southeast Asia. My argument is that in much writing about Irish popular music and culture, the normativity of the British example is assumed without debate - as indeed it was in the pages of the popular press at the time. Given all this, it is perhaps not surprising that a genre of music that, to certain eyes, seemed to encapsulate all that was un-modern and embarrassing about Ireland was the subject of much passionate disavowal.

Before going any further, however, we need to clarify some terms: country and Irish is often used indiscriminately to refer to all country music produced in Ireland, but, more properly, the term refers to country-ish music with a particularly Irish theme and reference to Irish place names and featuring instruments associated with Irish folk music, usually the accordion. Most country music that was popular in Ireland during and after the 'boom' was not of this type. Generally it consisted of straight cover versions of current country-pop songs from Nashville songwriters, performed in a manner close to the US model. The two subgenres were never mutually exclusive: almost all the more country and Irish artists would have performed 'straight' country songs, if only to pad out LPs, and many of the straight country singers would have dipped a toe the other way. In what follows, I will simply use 'country' to include both, and when a distinction is required, use 'straight' or 'pure' country to distinguish it from country and Irish.

Unless otherwise noted, 'Ireland' will refer to both jurisdictions on the island: until 1975, which saw the killing of five people, including three members of the Miami showband, by loyalist paramilitaries in Co. Down, and the subsequent refusal of most bands based south of the border to travel north, the showband scene was an all-Ireland one and, for the most part, the music crossed the sectarian barriers in Northern Ireland that so divided cultural life there in other respects before and after the outbreak of 'the troubles' in 1969. 


\section{Spotlight and New Spotlight}

Spotlight Magazine was founded in Cork in 1963 with a focus almost exclusively on the showband scene. From the beginning and throughout its lifespan, it functioned as a resource for both audiences and the music industry. Sections of it were devoted to insider gossip and business news while other sections mimicked the teen magazines of the time, with photos and profiles of showband stars. It moved to Dublin in 1966, added the 'New' to its title, and broadened its coverage substantially to take in the 'group scene' as it was known, in explicit opposition to the showband circuit. These were the rock bands that played the clubs of Dublin, Belfast and Cork. New Spotlight also covered the folk scene, one that, in turn was riven three ways between traditionalists, playing mostly instrumental music in non-commercial settings, the purveyors of 'the ballad boom', tending towards less raucous versions of the music made popular internationally by the Clancy Brothers and the Dubliners, and the new breed of pop-folk bands, such as the Johnstons and Emmet Spiceland, with Sweeney's Men operating to one side of those two, as a harbinger of the later, and much more sustained revival of traditional music in the early 1970s. All of these were competing for access to limited and state-controlled radio and TV exposure, and more importantly, to the wallet or purse of the live music consumer. As many - probably most - of the people who wrote for both iterations of the magazine were themselves active participants in the business, sometimes as performers, but more usually as managers or promoters, much of the feature writing in the magazine, and particularly the 'opinion' pieces, were anything but disinterested. New Spotlight, at its height - roughly 1968-1972 - had a circulation that peaked at 47,000. Proportionate to the population of the country, this is close enough to the reach of the 'inkies', the weekly music press in the UK at the same time. ${ }^{5}$

Before beginning to follow the origin story of Irish country as it was presented in Spotlight/New Spotlight, it would be useful to look more closely at the showband world as it existed in its 1960s heyday in Ireland. The scale of the dancehall scene can hardly be overstated. In an early issue of Spotlight, the opening of the Majorca Ballroom in Crosshaven, Co. Cork is noted, with a capacity of 3000 and a revolving stage. Crosshaven, even now, has a total population a few hundred short of that figure. ${ }^{6}$ Bands played five and often six nights a week through the year, bar Lent, when they would head for the UK or, later, the US.7 Given the state of Irish roads at the time, that meant long hours in the back of the van or bus and 70-hour working

5 The NME, at its 1960s peak, was selling 300,000 copies per week, a figure which was said to at least equal all the other UK music papers put together. So if we posit a total weekly sale of somewhere in the region of 600,000 for the UK weeklies, we get a figure of roughly one sale per 90 people given a UK population of 54 million in 1966. New Spotlight's circulation of 47,000 for a population across the island of Ireland suggests a figure of one sale for every 95 people.

6 It is worth noting that the showband scene, and the dancehalls that housed it, were by no means an exclusively rural phenomenon. As late as the 1980s, Dublin still had a few large halls in operation, and, at its peak, there were close to 20 halls partially or exclusively presenting showbands in the capital. The Arcadia in Cork, which in later years played a key role in fostering punk and post-punk music in that city, was perhaps the premier venue in the country with a capacity that, in times of less strict fire regulations, could reach 5000. However, the scene declined in the cities first, facing competition from nightclubs and later discos, and from the burgeoning rock scene, and the retreat to more rural halls perhaps exacerbated the musical shift to country.

7 The 40-day period between Ash Wednesday and Easter Sunday was strictly observed in predominantly Catholic Ireland until early in the 1970s. By order of the Catholic bishops, dancehalls were forced to 
weeks. The money, for the top bands, was excellent; many musicians were taking home $£ 100$ per week when the average industrial wage would have been a tenth of that (Power 1990/2000).

If the live scene was huge, and profitable, both for bands and a network of ballroom impresarios up and down the country, many of whom remained powerful players in the Irish and sometimes international music industry up to recent years, the record industry was close to non-existent in terms of originating product. Until the Eamonn Andrews Studio was set up in Dublin in 1963, there was no four-track facility in the Republic, and recording, for the few Irish acts that got the opportunity, required a trip to London, and probably a net loss of income, with lucrative gigs missed. There was no great rush to record among the showbands: with no radio outside of Radio Éireann, there was little chance of more than limited airplay.

The hostility to the showbands evident in Pat Egan's 'Group Scene' column in New Spotlight from 1966 onwards was not solely based on taste: the big money available to musicians in the rural dancehalls, away from the relatively small beat clubs of Dublin, was a constant temptation to members of the bands that populated that scene. Some effectively transmuted into showbands in order to tap into that seam: the Greenbeats, for example, widely considered Ireland's first beat group, added horns and took to the circuit, widening their repertoire accordingly. Others were solo defectors, picked off by showband managers to fill vacant spots in their acts or, as we shall see, to form new bands to capitalise on trends. The reaction of the showband scene to new sounds was to assimilate them to the format, rather than to change the format. The Plattermen, for example, formerly the Platters, became a 'progressive' showband, with long hair and psychedelic clothing, and covered songs by Laura Nyro and Blood, Sweat and Tears, but all still performed in the same venues, with the same long sets, and intermixed progressive sounds with more standard fare.

As noted, within the varied repertoire of the showbands in the early to mid-1960s, a certain amount of country music would be heard. It would seem from the early issues of Spotlight that genre specifications were somewhat underdetermined: country, in the early 1960s at least, was a flavour of popular music, not a separate practice with its own distinct criteria regarding performance or sociality.

One obvious contributor to the popularity of the showbands was the relative unavailability of the 'real' thing; tours by US and even UK acts were infrequent. In 1963, however, a few US country singers did make it to Ireland: Hank Locklin, Jim Reeves and Johnny Cash all toured. Nor were they confined to the cities: Cash played 16 shows, including dates in relatively small towns such as Mullingar, Mallow and Athy (Spotlight, 14 October 1963). Reeves played an equal number of shows, often playing twice a night in different halls. Reeves, for one, was not happy with this, and Spotlight reports less than enthused audience who found him distant and unengaged. In what reads like a somewhat perfunctory interview he said that the 'audiences in Ireland were among the best, the pianos among the worst' (Spotlight, 6 June 1963).

Even as early as 1963, a few Irish showband singers had become identified as country: Larry Cunningham, who had a very minor hit in the UK with 'A Tribute to

close, and, although such edicts had no legal force in what was, at least officially, a secular republic, none dared defy the church. 
Jim Reeves', was one; Brian Coll, who alternated vocal duties with Rob Strong in the aforementioned Platters, was another. As a rule however, country music remained an occasional exotic element in the showband mix. This began to change with the emergence of a handful of singers who inaugurated the particular amalgam of country-ish tunes with specifically Irish themes, or at least themes redolent of the kind of Irish-ry that informed the sort of ballads produced by Tin Pan Alley lyricists of an earlier generation. Chief among them was Big Tom McBride and his band, the Mainliners, who had a sizeable hit with their 1966 recording of 'Gentle Mother'. The Mainliners played the same circuit as the more mainstream showbands but were distinguished by having an identifiable sound that mixed country vocal tropes and harmonies with, as Maguire notes, a kind of 'swing' drumming that recalled the céili bands of an earlier time. ${ }^{8}$

The rise of Big Tom and Larry Cunningham, who increasingly gravitated towards more 'Irish' material as the 1960s went on, was a source of some embarrassment even at the time. Perhaps ironically, the showbands, the focus of scorn from the beat groups, were themselves a little dismissive of this new-old thing. Certainly, much of the coverage Big Tom received in New Spotlight after his breakthrough hit, 'Gentle Mother', was defensive: Tom, in one unlikely interview, claimed to know 'all about Jethro Tull' and the like, but knew that this stuff wouldn't do it in the dancehalls (New Spotlight, 17 August 1968).

Flanking this boom in sentimental Irish themed country-ish songs was a growing corps of 'real' country bands. What is crucial is that this trend was turned into a 'boom' by an industry that was extremely professional when it came to building and sustaining revenue streams in the dancehalls. Also, although the recording side of the industry remained underdeveloped, increasingly bands were launched with singles before being unleashed on the live circuit. Release Records, formed in Dublin by Michael Clerkin in 1968, was an important element in this: not initially intended to be an exclusively country label, the majority of its early recordings fell into that category, and, more importantly, they picked up on and promoted artists that were not yet established on the live circuit. ${ }^{9}$ Alongside the manufacture of this boom went the creation of a narrative about country music, about its suitability for Irish audiences as a closer fit than pop, and about its 'genuineness' that recognised a growing split between the urban and the rural, young and old, and foreshadowed the eventual passing of the showband circuit.

A sign of an explicitly country-focussed subsection of the industry in Ireland was a series of articles in New Spotlight in 1969 written by Des Kelly, who had formed and effectively managed the Capitol showband in the early 1960s, while still a student. He was the country singer in the band, though they were, for the most part, a pop-oriented outfit, with, unusually, many original songs written specifically for them by Phil Coulter. Kelly had recorded and had a big local hit with 'Streets of Baltimore', a hit for Bobby Bare in the US, and was quick to capitalise on what he had identified as a growing appetite for country in the ballrooms. Soon he was managing the Smokey Mountain Ramblers, assembled around Polish bluegrass fiddler

${ }^{8}$ Maguire (2012) goes into some detail about the influence of the céili bands, rural dance ensembles playing arrangements of traditional Irish dance tunes, on the showbands and the continuities in personnel and in playing style between these largely amateur outfits and their country ' $n$ ' Irish successors.

9 Until 2016, Michael Clerkin managed the career of Daniel O'Donnell and ran Ritz records that issued his recordings. 
Jerzy Kryzanowski (who operated as Gerry Kaye), and including two former members of Dublin beat group, The Movement. His four-part series on country music for New Spotlight over May and June of 1969 cannot, therefore, be taken as entirely objective.

In the second part of his series, headlined 'Will Country Music Last?' Kelly asserts that

Irish people have always liked this kind of music but it is only in recent times that people realised that it was a specific type of music with a definite title - country and western. (New Spotlight, 17 May 1969)

In the next issue of New Spotlight, there is an ad for a 'County Music Jamboree' to be held at the National Stadium in Dublin, featuring Willie Nelson, Nat Stuckley and Johnny Darrell from the US, alongside Irish acts the Smokey Mountain Ramblers, Des Kelly and the Tennesseans, and Shay O'Hara.

Meanwhile, Des Kelly continues his series on the music with a piece headed 'Why Country Music Appeals to Irish Fans'. After noting that the current revival in dancing is due in a big way to the new popularity of country music', he sets out what would become a key ideological figure of discourse, both friendly and hostile, around the Irish country scene:

People like this are catered for in country and western ... People who probably do a 16-hour day on the land or elsewhere and probably have little time to get acquainted with the latest that's happening in the world of pop. (New Spotlight, 24 May 1969)

By the time of the 21 June 1969 issue of New Spotlight, Des Kelly has a 'Country and Western Corner', and, perhaps not incidentally, the magazine also announces the formation of a new outfit, the Virginians, managed by none other than Des himself, and featuring a steel guitar player - so distinctive was this that the ad for their first shows in the same issue features a picture of said player, Basil Henrick (or Hendricks), an Englishman, and the instrument itself. In the same issue, Des Kelly is profiled as 'the man who started the C\&W boom, having scouted around for the musicians he needed from the showbands and the beat groups' and is reported to have invested more than $£ 5000$ in the Virginians.

Also announced in the same column is the reorganisation of the Cotton Mill Boys, from a five-piece, largely acoustic outfit, to a seven piece, retaining fiddle and banjo, but adding two guitars, bass, drums and organ, all these additions coming from rock bands such as the Creatures, Orange Machine and Blue, put together by the Tom Costello Organisation. Tom Costello had managed the Cadets, among others, fronted by Eileen Reid and one of the poppier and more youth-oriented showbands.

Over the course of the 1969 issues of New Spotlight, an unmistakeable sense of a country boom is reported: on 2 August 'all of the new releases are C\&W flavoured', on 12 September 'the big swing towards C\& W' is noted, and in the 26 September issue, it is reported that the Royal Blues showband, not previously noted for their devotion to the genre, plan a country LP.

Not all of the coverage is positive however, even outside of Pat Egan's 'Group Scene' cell of resistance. In the 17 October issue, Jim Hand, who worked as a promoter, band manager and PR person across the folk and showband scene, noting the fact that ' $\mathrm{C} \& W$ bands are mushrooming', wondered if 'we are all stark raving 
bonkers' and asked whether the present boom for 'black pudding music' was 'not the backlash of a dying generation?' In the same issue, Tony Wilson suggests that 'management and agencies are trying to force a boom' and concludes that many of the new bands brought into existence by these do not understand the music and play it badly, and that, in any case, country will never become the music for a mass audience and is 'best left to the enthusiasts'.

By 1970, as the record industry picked up momentum and as single releases by Irish artists became more common, the New Spotlight chart, while never dominated by $C \& W$, began to reflect the 'boom'. Consistently through the year, about a quarter of the top 20 consisted of Irish released country or country-flavoured recordings. The debate over whether the boom was to be short-lived or represented a sustained and sustainable feature of the Irish music industry continued: in the 11 September 1970 issue, a 36-date tour is announced for Slim Whitman, which proves, if nothing else, that plenty of ballrooms had survived a reported slump. In a trenchant piece in the 9 October issue, reviewing Whitman's Dublin show at the National Stadium, Des Kelly says the capacity crowd for this, as opposed to a poor turnout for an earlier package at the same venue featuring more contemporary country artists, proves that ' $\mathrm{C} \& W$ is alive and well' but also that 'Irish country music fans know what they like', which is 'songs with feeling, simplicity and, above all, sincerity' and that 'they will not be bulldozed into following blindly whatever publicists throw at them'. 'When I walked into the Stadium', writes Kelly, 'I feel that we were somehow sharing a common bond'. Country music, he concludes, is still 'THE musical force in Ireland', followed by 'a mature, adult crowd'.

The same note is struck in an interview with Ray Lynam in the following issue (16 October), headlined 'No End in Sight for C\&W Boom'. Lynam represented a distinct, and at the time still a minority thread within Irish country music: he was fine singer, with instinctive good taste, and he recorded almost exclusively modern US country material, with often excellent performances from his band, the Hillbillies. When he first came to the attention of New Spotlight, with a debut release on Release, he was still a local performer, based in the Midlands, and was initially compared with Buck Owens, a singer he rarely actually sounded like. In this piece, he is more accurately compared with George Jones, some of whose material he would sing, and is quoted as claiming that the country boom, 'far from fading, is broadening and putting down roots'.

As we can see from the above, country music did not simply 'happen' in Ireland. It did not take root because something in the music 'resonated' with Irish folk music, or because the music, and its lyrical concerns, were in some way homologous to the conservative tropes within Irish society. Rather, both of these notions were offered in support of a genre that was explicitly promoted in opposition to pop and rock and calculated to appeal to an audience outside the bigger cities. Some of this narrative was borrowed from the US country music industry of the period, where the battle lines between it and rock were drawn along much more explicitly political lines..$^{10}$

10 Irish country music never, to my knowledge, sounded an explicitly political note, but the identification of the music with rural Ireland, and the assumed traditional values that held there meant that it often appeared, to urban eyes and ears, to chime with the anti-modern, socially conservative strains in Irish political life, strains that were in explicit conflict with more liberal mores through the 1970s and into the 1980s. This impression was strengthened by the close relationship between some figures in Fianna Fáil, the ruling centre-right party in Ireland for most of the post-war period, with the dancehall scene and with country music. Albert Reynolds, Taoiseach (Prime Minister) between 2002 and 2004, made his 
The narrative was eagerly taken up by those less enamoured of this development and, as we will see, fed into what was to become the dominant critique.

\section{'Wake up showbands!'}

Some people harbour the stupid impression that it is unpatriotic to follow progressive groups, especially those outside this country. They would also urge us to buy the usually disgustingly inferior Irish versions of numbers previously recorded by British or American groups. There is no place for false patriotism on the pop scene. The lack of originality in Irish outfits is appalling.... The way to awaken those showbands who are years behind the times is to ignore them for a while.

Love and Peace,

Mary Lennon,

Co. Tipperary

(Letter to New Spotlight, 18 September 1970)

New Spotlight was, as noted, the only mass-market music magazine in Ireland at the time and, as such, the devotees of all the contesting genres and scenes that constituted Irish popular music came up against each other, provoking vigorous debate in both the columns of the paper and on the letters page. As Mary Lennon's letter shows, the appeal to 'Buy Irish' cut little enough ice with the consumer who was eager for the excitement and originality offered by rock.

In a similar manner, the showbands have often been presented in the literature as the enemy, the problem to be 'solved' before Ireland, and Irish music, could fully participate in the modern world. In two popular histories of Irish rock, both published in the 1990s, this disdain is evident. As Tony Clayton-Lea and Richie Taylor, begin their book:

In the beginning were the showbands and they ruled the land. A peculiarly Irish phenomenon, sporting neat hairstyles, and dressed in shiny suits [churned out] non-stop cover versions with various degrees of competence. (Clayton-Lea and Taylor 1992, p. 1)

A slightly more nuanced version of history is provided by Mark Prendergast in Isle of Noises:

In the beginning you had the showbands and very little else. [...] They controlled the dissemination of popular music throughout the country. Records were a secondary thing to the showband since it was the live event that generated the money. Artistic integrity and creativity were subsumed under the primary motive of profit.

And later:

In certain quarters the showbands were regarded as a plague. Even though the bands were very professional there was something missing ... in a word sophistication. There was something very superficial about the showbands. (Prendergast 1987, pp. 1-2)

fortune through a string of dancehalls in his native midlands and Paschal Mooney, once London correspondent of New Spotlight, and later a promoter and DJ, took a seat in the Seanad, the upper house of the Irish Parliament, and was known as 'the country ' $n$ ' western senator'. Reynolds's nephew, John, incidentally, became a successful rock and dance music promoter from the 1990s onwards until his untimely death in 2018. 
Smyth (2005), Hogan (2016) and McLaughlin and McLoone (2000) all mount what we might call a 'stage-ist' defence of the showbands: they were a necessary step in the development of an indigenous music industry, and acted as a nursery for musicians who later went onto better things.

Regardless of the perceived value of their musical contribution, the extramusical social effects of the showband era on Ireland's youth population should be recognised. (Hogan 2016, p. 264)

And

[The showbands] laid the foundations for future developments in Irish popular music. Influential artists including Van Morrison, Rory Gallagher and Henry McCullough started their careers in the showband scene. (Hogan 2016)

Smyth is even more forthright:

Nowhere is the arrogance of the present more visible than in the disdain shown towards the showbands by subsequent generations, those who didn't have to contend with the fifties [...] as Irish culture materially improved from the 1960s, and as it 'matured' towards standard international middle-class values, it turned its back on the pleasures, now regarded as coarse and callow, that characterised its first brush with the modern world. (Smyth 2005, p. 17)

The hostility of Clayton-Lea and Taylor, and Prendergast, and even the more sympathetic accounts offered by Smyth, Hogan, and McLaughlin and McLoone, are grounded in the two discursive figures that McLoone and McLaughlin (2000) identify as foundational for the development of popular music criticism, both in its journalistic form and in its later academic incarnation. These notions are the various iterations of 'the authentic' as a quality explicitly contrasted with the commercial or 'manufactured', and the priority of youth as the vanguard of originality and innovation. The first is captured in the following quote from Motti Regev:

Rock culture has been characterized by a constant struggle, waged by musicians, fans and critics, to distinguish the authentic and the genuine from the purely 'commercial', and to define a sense of difference and distinction. (Regev 1997: 129)

And the second is contested here by Charles Hamm:

This narrative [of youth culture] has no relevance for groups in which age distinctions are less important, such as African-Americans and other marginalized ethnic populations, nor for entire popular repertories such as country-western music which appeal to people of all ages within a given cultural field; and it's virtually useless in dealing with non-Western societies. (Hamm 1995, p. 23)

The concentration on live performance, the relative lack of interest in recording, the absence of original material in the showband repertoire, and the stylistic promiscuity of the bands, made the whole scene opaque to notions of value and meaning derived from a rock aesthetic. The showbands were not 'authentic' in any of the three persons enumerated by Allan Moore. They did not express either the 'genuine' experience of the singer or of the audience, nor did they enact a fidelity to a set of defined musical practices. The things that were valued in a showband - versatility, slickness, the ability to accurately imitate the music of others - are all alien to sensibilities attuned to the claims of rock and related genres (Moore 2002). Unlike the cover bands of today, 
however, they did not disappear behind the material; some showband musicians were genuine stars in the Ireland of time.

Along with the lack of concern for such notions of authenticity, the showbands were not 'youth-oriented' in the sense described by Hamm. Although younger people formed the majority of the dancers in most of the halls, the culture was not exclusionary, or aggressively incomprehensible to adult sensibilities; it could not afford to be, nor could the bands afford to direct themselves to specific audiences or taste cohorts. The idea of a 'cultural lag' was present even at the time, as the letter quoted above illustrates: the same view, that Ireland needed to catch up with rock and pop culture in the USA and in Britain, is posited more than once in the literature. Thus O'Flynn and Fitzgerald note that 'in popular music, developments [in Ireland] lagged behind Britain and America until the late 1970s' (Fitzgerald and O'Flynn 2016), without examining exactly why 'Britain and America' should be the index of progress for a country that was, in many decisive ways, quite different. A more forgiving, and more contextualised, attitude to the showbands has been exhibited in the literature. We have not seen anything similar with regard to their country successors: the showbands being safely confined to history can be forgiven, but the persistence of country and Irish, despite everything, remains an embarrassment.

\section{Pickin' on country?}

Country and Western bands here have been accused of doing too much American material. But this isn't confined to the $\mathrm{c}$ and $\mathrm{w}$ outfits. Our beat, pop and folk people also copy the styles of the United States and other countries. The mimicry is not confined to music. We unconsciously copy, sometimes even ape, the culture politics and modes of life of other peoples. We are all at fault in this kind of imitation so it isn't really fair to knock the C\&W bands on this score.

Gary Pepper,

Co. Clare

(Letter to New Spotlight, 23 October 1970)

As we have seen, Gerry Smyth defends the showbands from the 'condescension of history' and suggests that, far from being embarrassing relics, they were, in their time, exemplars of the form modernity would take in Ireland. Perhaps oddly then, in an earlier, autobiographical piece about his own experience as a musician, he writes of his embarrassment and annoyance at being forced to perform certain types of material while working in bars in Europe:

I have to admit, I found this kind of music incredibly boring, reminding me of the crass sentimentalism that passed for entertainment back in Ireland under the generic title 'Country and Irish'. In recent years Daniel O'Donnell has exploited this market brilliantly and along with U2 is probably Ireland's most successful cultural export of the 1980s. (Smyth 1992, p. 4)

It is, obviously, mischievous to pick on him for this, but it does illustrate what remains a prevailing attitude towards country and Irish amongst anyone in Ireland with any claim to urbanity.

In one of the few defences of the music and its milieu I was able to locate in the literature, Julian Vignoles, who wrote for Hot Press in its early years, writes in the Crane Bag in 1984:

Let's take another definition of popular Irish music; any music that's popular only in Ireland. Irish country and western comes into this category and without doubt is part of Irish popular 
culture. A large section of people - young and old - identify with the feelings and sentiments of the songs. The irony is that this music [is] despised by people who've a more 'sophisticated', urban musical taste. [...] People like Big Tom, Susan McCann or Ray Lynam are no poorer in charisma or stagecraft than many 'Top of The Pops' acts. But their heartland, the 'dry halls' of Ireland, has shrunk to two north western counties. Fashion and the disco and liquor combination now available have won the day. The dance band scene, apart from a few hardy exceptions, is vanquished. There was no High Noon. (p. 3)

The obituary was, as we have seen, premature: the dance halls have gone, but two out of the three names mentioned still tour, and they have been joined by many younger performers, now playing the function rooms of hotels and concert stages, and on frequent overseas tours. The embarrassment, however, remains.

What critical commentary there still is on Daniel O'Donnell, 30 years later, exemplifies this. Stokes 1999 explicitly links the devotion he finds in the fan-culture around O'Donnell, one of Ireland's more successful music exports, to what he sees as echoing patterns of popular religious practice. MacLaughlin accuses the Donegal singer of providing an inevitably synthetic and illusory 'Oasis of Innocence in a Cruel and Wicked World' (1997). He goes on to condemn him for a perceived inauthenticity and explicitly posits an 'authentic' antipode:

Not least of the ironies surrounding $\mathrm{O}^{\prime}$ Donnell is that he hails from the same county as Clannad. However, unlike O'Donnell's lyrics, their music is firmly rooted in the county, in the Rosses, and in a highly inventive and rich Gaelic tradition of music making. O'Donnell does not so much make music as purvey it. Like Enya, moreover, he's not from any place in particular. He's certainly not from any 'real' or recognisable Donegal. (MacLaughlin 1997, p. 141)

\section{‘Go Progressive RTE!'11}

What a pity that so many Irish music lovers go for country and western when there is so much more to enjoy. I wonder if this situation has been brought about by Radio Eireann which seems to play so much C\&W. If people heard artists like John Mayall, Deep Purple, Pioneers, Brotherhood of Man (!) or Rare Bird, would they forget their country idols? So, RTE, how about more progressive music and less of the sloppy country? And please Spotlight, more pictures of up-to-date groups for lovers of progressive, blues, reggae and pop music.

Josephine Vaughan,

Co. Limerick

(Readers' Letters, New Spotlight, 20 February 1970)

The imperatives of the rock ideology regarding youth and authenticity were felt all the more keenly in their absence by some in Ireland, owing to the proximity of Britain and the permeability of all levels of Irish society, perhaps more particularly on the east coast, thanks to British radio and television, and to the cultural products

11 RTE (Raidio Telefis Éireann) was and is the national broadcaster in Ireland. Until 1979, it comprised a single radio station and, from 1961, one TV station, both of which had monopoly status, although competition from a growing number of pirate stations eventually forced the hand of the government to introduce both a second RTE 'pop' station, and to license commercial local radio. The monopoly was never complete, however, as much of the country could receive BBC radio and, particularly on the east coast, BBC and ITV television. RTE's funding model was, and still is, a hybrid of the licence fee model copied from the BBC and advertising. During the period in question, much of this advertising revenue was gathered in the form of sponsored programme content and these were often the chief outlets for domestic recorded music. 
of the larger island. Reading some of the letters in New Spotlight, and some of the opinion pieces, there is a definite sense that Ireland is culpably failing to keep up. The showbands are excoriated for not writing their own material and Irish records are dismissed as weak and tinny sounding by comparison with the products of the British pop scene at a creative peak. This 'cultural cringe' intensified as the presence of country music increased and what was seen as the gulf between popular music in Britain and Ireland grew wider.

It is perhaps inevitable that the British experience of popular music would appear normative in Ireland and that the perceived underdevelopment of the music industry in certain respects, and the noticeable divergence in this regard from what was still, for many Irish people, the cultural magnetic pole, would be felt as a cause for embarrassment by some. This internalisation of the 'gaze of the coloniser' is a mainstay of postcolonial theory and is employed by McLaughlin and McLoone as a key conceptual frame within which to position their analysis of what they see as the development of a hybrid modernity in Irish rock and associated genres. The question as to whether Ireland can be usefully regarded as a postcolonial society has been extensively debated across many disciplines; there is not the space to discuss this fully here. ${ }^{12}$ It is impossible, however, to read New Spotlight through the late 1960s and into the 1970s without grasping a complex and often contradictory relationship with the neighbouring island and its musical cultures and music industry. Whether this was intensified or not by the historical, asymmetric interpellation of Ireland and Britain is hard to fix precisely. Some of the features of that relationship were the result of large-scale emigration to British cities by young Irish people in the 1950s and into the 1960s before the economic regeneration sparked by Lemass's industrial policy bore fruit. ${ }^{13}$ As mentioned above, dancehalls in Ireland generally closed for the 40 days of the Lenten period and the showbands often took to the circuit in Britain. Many of the venues were exclusively or predominantly 'Irish' dancehalls, but, unlike their counterparts at home, they were licensed and a great deal more comfortable. Most of the Irish emigrants that filled these halls had come from rural communities in the west of Ireland and the relocation to large, industrialised English and Scottish cities could not but greatly alter their sense of themselves and their world. For women in particular, financial independence away from a repressive moral regimen at home, and the possibility of career advancement even after marriage softened the blow of exile considerably. Nevertheless, although in certain respects, the Irish emigrant experience diverged considerably from that of those left behind, the links with home remained strong: large amounts of money would be sent back as remittances and, when children arrived, they would be sent to the grandparental farm for summer holidays. Perhaps unusually, a consequence of this mass emigration to a country close enough for regular and sustained contact to be maintained between those leaving and those left meant that working-class

12 For wider discussions of Ireland and the postcolonial condition, see, for example, Kiberd (1997) and Lloyd (1987, 1993).

13 Eamon DeValera, who had been Taoiseach for most of the years from 1932 onwards, was replaced in 1959 by his long-time deputy, Seán Lemass. In concert with the chief secretary of the Ministry of Finance, T.K. Whitaker, Lemass lost no time in reversing years of economic isolationism and protectionism, instituting a new industrial policy centred around attracting foreign direct investment, largely from the US. The effect was transformative, moving large numbers of people from dependence on agriculture into a wage economy. The effect was such that most periodisations of Irish history take 'modern Ireland' to start here (see Lee 1990). 
and rural people in Ireland were possibly more 'cosmopolitan' in a concrete sense of having experience of life elsewhere and regular contact with a quite different situation than a more 'provincial' middle class.

This is relevant because official Irish culture, almost entirely in the hands of that middle class, even as the country opened up economically through the Lemass years and after, remained rigidly confined by the postcolonial paradigm outlined by McLaughlin and McLoone. This culture was as suspicious of difference as the colonial culture it had replaced, and, furthermore, was unusually 'anti-modern' in many respects. Certainly, however accurately the Irish situation fits the postcolonial model, an anxiety about identity, and about 'Irishness', characterised much of the discourse about culture in the half-century following independence. The native ruling class were capable of all sorts of projections upon 'the plain people of Ireland' and even more so onto the Irish-speaking portion - a projection, and a concern, that almost killed the language. Music in Ireland was similarly over-burdened with responsibilities. As Harry White has convincingly argued, music was, from the early 19th century onwards, almost entirely enlisted in the service of nationalism. Folk music, often imperfectly understood, and reproduced as 'tidied up' harmonically, came to occupy the place of language as the index of Irish identity at the price of any successful encounter with art music, as occurred in other European countries arriving at national self-consciousness around the same time. An unexamined belief in the inherent musicality of the Irish, itself inherited from 'the view of the coloniser' meant that, as White has it, 'the idea of Irish music [had] a metaphorical power that eclipse[d] any cultivation of music per se' (White 1998, 152). It is, of course, impossible to keep a practice as promiscuous and indeterminate as music 'pure' but, as McLaughlin and McLoone note, it did not stop some from trying:

In terms of music, the essentialist notions that underlie dominant conceptions of 'Irishness' (and which are most characteristically applied to Irish traditional music) can be seen on the one hand as ideologically conservative and analytically restrictive, privileging 'nature' over culture and alluding to a deep essence of Irish-ness that withstands historical change. (p. 182)

It was a view that functioned on the suggestion of 'homologous links between traditional music and the values of a homogenous and harmonious Irish population' (Fitzgerald and O'Flynn, 2016, p. 2). McLaughlin and McLoone posit that the site of negotiation with globalisation is located not in the defence of an illusory essentialism but at the point where the local meets the global and a hybrid, only possible at the point, comes into being. For them, in the Irish context, this synthesis occurs in a specific set of Irish rock texts: Van Morrison, Horslips, the Pogues and Sinéad O'Connor.

As McLaughlin and McLoone argue, the narrative of globalisation in music is no longer one of homogenisation, but rather one in which difference is identified and then marketed, and one that releases liminal 'energies' that flow from the encounter between the periphery and the centre. Irish musicians, and the Irish music industry, in recent decades, has been very good at managing this encounter, using their simultaneous proximity to the centre in Britain (and the US by virtue of language and cultural sympathy) and the ability to strategically distance itself from that centre when it suits in order to insert various modes of 'Celtic-ness' into world music, rock and pop. In this framework, country and Irish is exactly what we do not want to fall beneath the 'English gaze'. It might be the case that, when 
Irish rock and related forms have shown the ability to successfully market a version of Ireland and Irishness abroad that seems to harmonise nicely with an open economy and a liberal social dispensation, this cultural model has replaced the more rigid 'purism' outlined above, but with the same anxieties concerning divergent cultural forms that do not perfectly reflect a favoured, differently curated version of Ireland.

It might be argued, perhaps provocatively, that this 'release of liminal energies' is exactly what happens in country and Irish, where the global - country - in its most deracinated form, the soft pop of countrypolitan, meets a version of Irish music that is itself a re-working of the Tin Pan Alley Irish-ry of the early 20th century. The obvious popular appeal of this from the 1960s onwards, and its stubborn refusal to go away and leave the field to music that performs the alchemy of modernity (or postmodernity?) in the conjunction of respectable Irish forms framed by the global and romantic discourse of rock and associated musical forms, provokes precisely that desire to repress the internal adversary.

Irish country music, in all its forms, colonised a space between the centre and periphery through the rich network of communication and cultural transmission between rural Ireland and Irish emigrant communities in British cities and was, in its way, a lot more quietly cosmopolitan in its reach than Irish rock music before the late 1970s, anxiously courting the attention of a largely oblivious British market. There is a somewhat caricatured impression that Irish country music of the kind that was popular in the late 1960s and into the 1970s was predominantly concerned with sentimental visions of home, working placenames into clichéd narratives of emigration and longing. There was some of this, but interestingly, much of the music that was popular in the dancehalls of both Ireland and Irish Britain spoke of life in often more modern terms than one might expect for an audience that was considered socially conservative by critics of the music. So, for example, many popular country hits of the time spoke of infidelity and divorce at a time when the latter was unavailable in Ireland. Among the biggest hits of the period in this genre were Ray Lynam's version of 'If We're Not Back in Love by Monday' and Philomena Begley's 'Don't Let Me Cross Over (Love's Cheating Line)'. Much of this can be attributed to the fact that most of the songs were imports from the US country scene, but the popularity of such topics suggests a more nuanced understanding of life and its complications than the disdainful view of rock sophisticates would allow.

One small final point: for second-generation Irish people in Britain growing up the 1960s and 1970s, country and Irish seems to have been relatively free of the embarrassment it caused at home. As members of this generation went on to create music themselves, they recalled this: one obvious instance is the line in Shane McGowan's 'A Pair of Brown Eyes', remembering 'when Ray (Lynam) and Philomena (Begley) sang of "My Elusive Dreams"' (on The Pogues, Rum, Sodomy and the Lash 1985, Stiff Records). Another, more recent example, is the Dexys' album from 2016, Let the Record Show: Dexys Do Country and Irish Soul (2016, 100\% Records), which reimagines the music of Irish emigrant life in London and the English midlands, where Dexys singer Kevin Rowland grew up. It mixes folk, ballads, pop, soul and country in exactly the way this would have happened in the singsongs at Irish weddings, birthdays and funerals, without any snobbery, genre distinctions or looking over the shoulder. Sometimes it seems as if it might be a lot less complicated being Irish somewhere else. 


\section{References}

Spotlight and New Spotlight magazine were published by the Creation group, first in Cork and later in Dublin from 1963 until 1980 (as Starlight for its final years) The National Library of Ireland holds an almost complete collection, and thanks is due to the staff there who, as always, were unfailingly helpful.

Blake, A. 2013. 'Listening to identity: music in 21st century Ireland', Irish Journal of Applied Social Studies, 16/1, pp. 115-27

Clayton-Lea, T., and Taylor, R. 1992. Irish Rock: Where it's Coming From, Where it's Going To (Dublin, Gill and Macmillan)

Finnegan, R. 2007. The Hidden Musicians (Middletown, CT, Wesleyan University Press)

Fitzgerald, M. and O'Flynn, J. 2016. 'Introduction', in Music and Identity in Ireland and Beyond, ed. M. Fitzgerald and J. O'Flynn (London, Routledge), pp. 1-16

Hamm, C. 1995. Putting Popular Music in its Place (Cambridge, Cambridge University Press)

Hogan, E. 2016. 'Music in Ireland: youth cultures and youth identity', in Music and Identity in Ireland and Beyond, ed. M. Fitzgerald and J. O'Flynn (London, Routledge), pp. 259-72

Kiberd, D. 1997. Inventing Ireland (Cambridge, MA, Harvard University Press)

Lee, J.J. 1990. Ireland 1912-1985. Politics and Society (Cambridge, Cambridge University Press)

Lloyd, D. 1993. Anomalous States (Durham, NC, Duke University Press)

Lloyd, D. 1987. Nationalism and Minor Literature (Berkeley, CA, California University Press)

MacLaughlin, J. 1997. 'The music of Daniel O'Donnell: an oasis of innocence in a cruel and wicked world', in Under the Belly of the Tiger: Class, Race, Identity an Culture in the Global Ireland, ed. E. Crowley and J. MacLaughlin (Dublin, Irish Reporter Publications), pp. 139-47

McLaughlin, N., and McLoone, M. 2000. 'Hybridity and national musics: the case of Irish rock music', Popular Music, 19/2, pp. 181-99

Maguire, P. (2012) Conditions of Possibility: Changes in Popular Music Culture and the Development of Country $\mathcal{E}$ Irish Music, Unpublished PhD thesis, University of Ulster

Miller, R. (2014) 'Hucklebucking at the tea-dances', Popular Music History, 9/3, pp. 225-47

Moore, A. 2002. 'Authenticity as authentication', Popular Music, 21/2, pp. 209-33

O'Connor, N. 1991. Bringing it All Back Home: The Influence of Irish Music (London, BBC Books)

O'Flynn, J. 2009. The Irishness of Irish Music (Farnham, Ashgate)

Ó Súilleabháin, M. 1981. 'Irish music defined', The Crane Bag, 5/2, pp. 83-7

Power, V. 1990/2000. Send 'Em Home Sweatin': The Showband Story (Cork, Mercier)

Prendergast, M.J. 1987. Isle of Noises: Rock ' $n$ ' Roll's Roots in Ireland (New York, St Martin's Press)

Regev, M. 1997. 'Rock aesthetics and musics of the world', Theory, Culture, and Society, 14/3, pp. 125-42

Smyth, G. 1992. 'Who's the greenest of them all? Irishness and popular music', Irish Studies Review, 2/3, pp. 3-5

Smyth, G. 2005. Noisy Island: A Short History of Irish Popular Music (Cork, Cork University Press)

Stokes, M. 1999. 'Afterword: music and tourism', World of Music, 3/1, pp. 141-5

Vignoles, J. 1984. 'What is Irish popular music?', Crane Bag, 8/2, pp. 70-2

White, H. 1998. The Keeper's Recital: Music and Cultural History in Ireland 1770-1970 (Cork, Cork University Press) 